\title{
“ФІЛОСОФІЯ РЕЛІГІЇ ТА МЕДИЦИНИ В ПОСТСЕКУЛЯРНУ ДОБУ”,, ОГЛЯД ІІ МІЖНАРОДНОЇ НАУКОВО-ПРАКТИЧНОЇ КОНФЕРЕНЦІЇ
}

\author{
Ірина Васильєва \\ доктор філософських наук, професор, \\ завідувач кафедри фрілософії, біоетики та історії медицини, \\ Національний медичний університет імені О. О. Богомольця \\ ivafilos1403@gmail.com \\ ORCID 0000-0003-3772-5358
}

\section{Сергій Шевченко}

доктор філософських наук, профресор кафедри філософії, біоетики та історії медицини, Національний медичний університет імені О. О. Богомольця

ex.theology@gmail.com

ORCID 0000-0002-9713-3402

\section{Оксана Романюк}

кандидат філософських наук, доцент кафедри філософії, біоетики та історії медицини, Національний медичний університет імені О. О. Богомольця

RomanukOV@i.ua

ORCID 0000-0002-4077-8883

DOI: https://doi.org/10.34017/1313-9703-2020-1(15)-2(16)-114-124

11-12 червня 2020 року у Національному медичному університеті ім. О. О. Богомольця в онлайн режимі відбулася II Міжнародна науково-практична конференція "Філософія релігії та медицини в постсекулярну добу”, присвячена пам'яті Луки (В.Ф. Войно-Ясенецького). Базовою кафедрою в організації заходу виступила кафедра філософії, біоетики та історії медицини. Напрямки роботи учасників конференції залишились традиційними й були зосередженні на: питаннях взаємодоповнюваності релігії та медицини у житті і творчості святителя Луки (В. Ф. Войно-Ясенецького); окресленні світоглядних, методологічних, етичних, аксіологічних та історичних аспектів взаємозв'язку релігії та медицини у сучасному суспільстві; проблемі визначення та тлумачення здоров'я людини в контексті нових підходів у сучасній філософрії, релігії та медицини; необхідності подальшого діалогу між релігією та медициною в наш час; актуальних проблемах біомедичної етики в сучасному релігійному дискурсі; тих викликах, що загалом повстали перед релігією та медициною. Поряд з НМУ імені О.О. Богомольця співорганізаторами конференції виступили: Відділення релігієзнавства Інституту фрілософії імені Г.С. Сковороди НАН України; Центр розвитку особистості “HUMANUS", Пловдив (Болгарія); Інститут соціальної медицини та медичної етики медичного фракультету Університету імені Коменського в Братиславі (Словаччина).

В роботі конференції взяли участь представники більше двадцяти освітніх та наукових закладів України та Європи: Університету св. Єлизавети в Братиславі (Словаччина), Трнавського університету (Словаччина), Відділення релігієзнавства Інституту філософії імені Г. С. Сковороди НАН України, Київського національного університету імені Тараса Шевченка, Національного педагогічного університету імені М. П. Драгоманова, Донецького національного університету ім. Василя Стуса, Національного авіаційного університету, Національного транспортного університету (м. Київ), Національного університету біоресурсів і природокористування, Національної академії статистики, обліку та аудиту, Центру розвитку особистості 
"HUMANUS", Пловдив (Болгарія), Національного університету харчових технологій (м. Київ), Прикарпатського національного університету імені В. Стефаника (м. Івано-Франківськ), Сумського обласного інституту післядипломної педагогічної освіти та ін. Значне представництво учасників забезпечили провідні медичні та фармацевтичні заклади України та Європи, зокрема Інститут соціальної медицини та медичної етики медичного факультету Університету імені Коменського в Братиславі (Словаччина), Вінницький національний медичний університет імені М. І. Пирогова, Запорізький державний медичний університет, Івано-Франківський національний медичний університет, Львівський національний медичний університет імені Данила Галицького, Національний фармацевтичний університет (м. Харків), Одеський національний медичний університет, ПВНЗ "Київський медичний університет", Харківський національний медичний університет, Харківська медична академія післядипломної освіти.

Конференція вдруге засвідчила інтегративне спрямування представників соціальногуманітарних наук на дослідження духовності людини у сучасному постсекулярному інформаційному суспільстві і вагомість нових здобутків у фундаментальних, клінічних дисциплінах (анатомії, терапії, фрармації, біології та хімії, хірургії, онкології тощо).

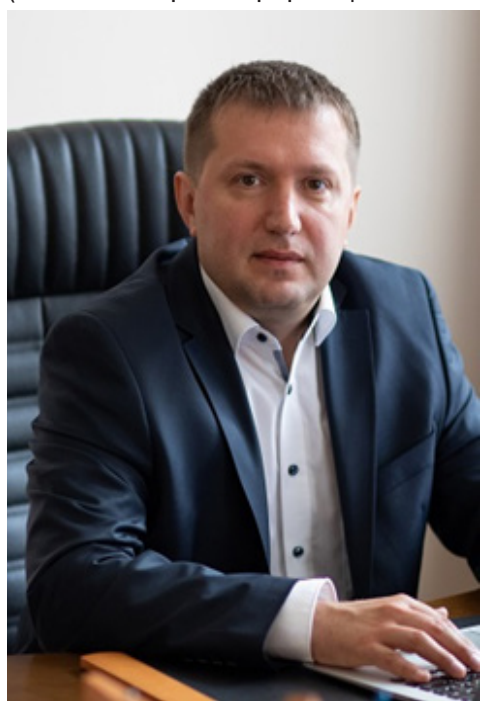

Конфреренцію з вітальним словом відкрив ректор університету, професор Юрій Кучин, який акцентував увагу на актуальності обговорення питань взаємодії релігії і медицини як в контексті історичної ретроспективи, так і сучасності. Ю. Л. Кучин відзначив, що біографія свт. Луки (В. Ф. Войно-Ясенецького) нерозривно пов'язана з Україною, з історією нашого університету. В 1903 році він з відзнакою закінчив медичний фракультет Київського університету св. Володимира. Після завершення університету, відмовившись від перспектив наукової кар'єри, В. Ф. Войно-Ясенецький присвячує своє подальше життя практичній медицині, багато років працює земським лікарем. У 1916 році на основі книги "Регіонарна анестезія" захищає дисертацію і отримує ступінь доктора медицини. Важливі здобутки, що містяться у таких його наукових працях, як “Нариси гнійної хірургії", "Пізні резекції при інфікованих вогнепальних пораненнях суглобів" тощо, стали дієвим фундаментом для підготовки багатьох поколінь медиків і залишаються актуальними й у сучасній медицині.

Учасників конференції привітали також проректор з науково-педагогічної роботи, міжнародних зв'язків та європейської інтеграції професор Р. Л. Скрипник, яка у своїй вітальній промові зазначила важливість долучення до наших вітчизняних конференцій представників зарубіжних навчальних закладів; проректор з наукової роботи та інновацій, професор С. В. Земсков відмітив, що не зважаючи на карантин, позитивною тенденцією в розви-
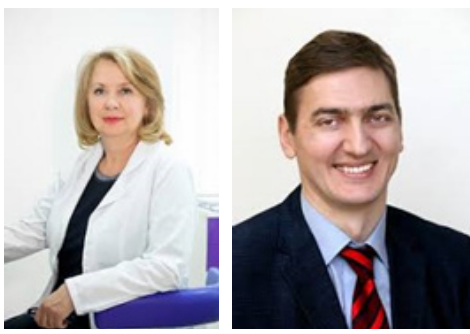
тку науковох діяльності в університеті $є$ і фрактор участі у конфреренції студентів, зокрема, клінічних ординаторів НМУ - іноземних громадян. На думку адміністрації університету, те, що пандемія не лише не завадила проведенню конференції, але й надала можливість представити й висвітлити свої наукові погляди великій кількості науковців, свідчить про глибинну актуальність проблем взаємодії і взаємовпливу релігії й медицини у сучасних умовах. 


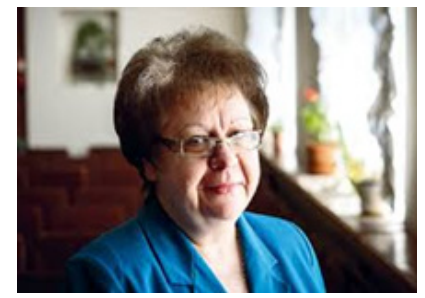

Віце-президент ГО "Українська асоціація релігієзнавців", завідувач відділу філософії та історії релігії Відділення релігієзнавства Інституту філософії ім. Г. С. Сковороди НАН України професор Л. О. Филипович відзначила важливість для української культури, релігієзнавства, філософії звернення до постаті свт. Луки, особливо в контексті налагодження діалогу між релігією та медициною, який є вкрай важливим у постсекулярну добу.

Пленарне та секційні засідання, хоча і проводилися в дистанційному режимі, утім, навіть кількістю учасників, гостротою обговорень та численними диспутами довколо актуальних питань, суттєво увиразнили та інтенсифікували формат минулих зібрань на традиційних очних конфреренціях. Модератор конференції, завідувач кафедри фрілософії, біоетики та історії медицини НМУ імені О. О. Богомольця, профресор І. В. Васильєва акцентувала увагу на "необхідності створення простору консолідованих зусиль вчених, медиків, богословів, фрілософрів, правознавців, політиків у питаннях, що стосуються глибинних проблем існування Людини у сучасному світі, особливо у зв'язку зі стрімким роз-

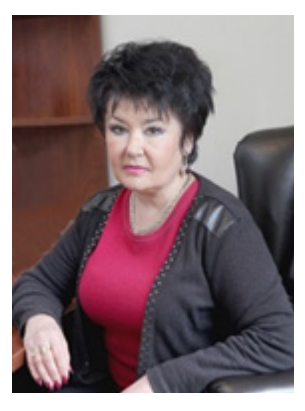
витком біомедичних, інфрормаційних, нанотехнологій, зростанням технічного забезпечення медичної практики. Універсальна система цінностей та світоглядних настанов, що властива християнській духовній традиції, на її думку, може бути не тільки основою для розв'язання найбільш контроверсійних питань медичної практики (аборти, евтаназія, клонування, допоміжні репродуктивні технології та ін.), але й виступати своєрідною противагою сцієнтистськотехнократичним, релятивістським та ліберально-радикальним підходам і поглядам. На думкуl. В. Васильєвої, людська гідність - це не просто властивість внутрішнього "Я" людини, але й вияв ставлення людини до Бога, до ближнього, до природи, до суспільства. Нагальною потребою сьогодення є і перехід від суб'єкт-об'єктного до суб'єкт-суб'єктного ставлення людей до собі подібних (кожна людська істота за І. Кантом є самоціллю, а не засобом), до інших живих істот, природи в цілому. У зв'язку з цим, принцип людської гідності може бути визначений як один з провідних принципів не лише медичної, але й глобальної біоетики".

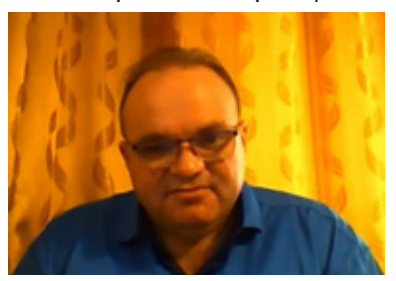

Старший науковий співробітник Відділення релігієзнавства Інституту філософрії імені Г. С. Сковороди НАН України, кандидат фрілософрьких наук О. В. Бучма у доповіді на тему "Релігія та право як детермінанти здоров'я людини та суспільства" доводив, що "ми є свідками того, що на руїнах цінностей минулих століть виникає, народжується новий, сучасний світ, світ модифікованої суспільної свідомості, що пропонує нові парадигми, які характеризуються складністю, випадковістю, відсутністю стабільних основ, непередбачуваністю. Всередині цього процесу на передній план висуваються релігійна і правова її (суспільної свідомості) форми. Природність комунікації між ними можна пояснити, відштовхуючись від природності й історичності зв'язку феноменів релігії та права. Людина і суспільство - трансчасові феномени, що перебувають у постійному русі від минулого до майбутнього. А теперішнє є лише певною миттєвою фазою між тим, що відбулося, і тим, що має відбутися. Тому, ймовірно, існує певний механізм, через який здійснюється зв'язок теперішнього з минулим (дія традиції), засобом якого успадковуються минулі символи, знання, цінності, вірування, правові норми. Вірогідно, що за своєю природою цей механізм ідеальний. А одним з дієвих його варіантів і є релігія, яка, поєднуючи в собі світоглядні установки, життєві норми і містичне почуття, сполучає людину і суспільство з їхнім минулим, акумулює колективну пам'ять, закла- 
дає потенційні можливості майбутнього". О. В. Бучма наголосив й на тому, що сучасні зміни в інформаційних та біологічних технологіях піднімають лаштунки над таємницею життя. Але позитивно впливаючи на цивілізаційний розвиток, вони подеколи спричиняють й кризові явища в сфері духовного життя. Так зване духовне занепокоєння й виникає внаслідок застосування нових експериментальних технологій в керуванні масовою та індивідуальною свідомістю, практикою генної інженерії тощо. Не тільки людське тіло, але й дух (душа) потрапляють в сферу товарних відносин, уречевлення. Відбувається й десакралізація суспільного життя. Усе це може вкрай негативно позначатися і на стані духовного здоров'я людини та суспільства. У цій ситуації вирішенню окреслених проблем і подоланню кризових явищ безумовно сприятимуть подальші дослідження в галузі релігієзнавства та права (особливо дослідження специфіки функціонування релігії в ситуаціях релігійної нетерпимості, заангажованості, деструкції і умовах дії права, наприклад, в тоталітарних, авторитарних режимах, дії неправових законів, нехтування/порушення прав людини тощо). Тому, на глибоке переконання вченого, важливим $€$ й створення глобальної системи саморегулювання зв'язків людини з навколишнім світом і детермінантами соціального, духовного, психологічного і фізичного здоров'я суспільства.

Завідувач кафедри філософії та економіки Львівського національного медичного університету імені Данила Галицького професор І. 3 Держко у доповіді “Метафізика здоров'я та феноменологія людини" наголосив на тому, що розуміння фізіологічних паталогій і хвороб так само, як і пошуки дієвих шляхів їхнього подолання завжди мали конкретно-історичний характер, а науковий прогрес далеко не гарантує швидкоплинного розв'язання

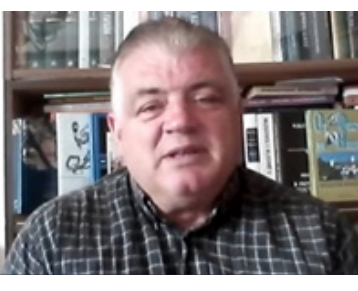
усіх проблем та створення універсальних середників та ліків від будь-якого захворювання. Різноманітні ритуальні механізми впливу на здоров'я та визначення тих чи інших лікувальних засобів, були невід'ємною складовою навіть у первісних окультних уявленнях та магічних діях. Монотеїзм, який досяг статусу тієї чи іншої релігії, також пропонує певний набір духовних засобів впливу на тілесну патологію та психічні розлади. Проте, релікти окультизму та міфічного світобачення постійно відроджуються у різних замаскованих формах новітніх вірувань. Новітні псевдорелігії та секти закликають до екстатичного впливу на потойбічне, та поновлення ресурсу окультних дійств, давно засуджених християнством. Реклама в масмедіа чаклунів, віщунів, новітніх магів та шаманів, різноманітних гороскопів, як це не дивно, подеколи і сьогодні поширюється разом із текстами суто християнського спрямування. Професор I. 3 Держко зауважив й на тому, що власне «об'єктивізовані методи» лікування почали формуватися у той час, коли людина усвідомила, що ідеальні поняття, моральні принципи зокрема, є обов'язковими, як і фізичні, хімічні, біологічні закони, коли розпочався процес обґрунтування та трактування появи страждань та недугів, як об'єктивних феноменів, що мають свої закономірності, власні причини та наслідки. I хоча ще не народжена етіологія була, наповнена ірраціональним містичним змістом, об'єктивні вимоги розпочали діяти раціонально, і змушували використовувати по-справжньому “кентавричні” уявлення для трактування хворіб та використання цілого пакету лікувальних засобів та маніпуляцій. При цьому раціональне вирізняло певні ланки етіопатогенезу в цілому та спрямовувало думку до правильного діагностування і ефективного лікування. Цілительство поступово та впевнено трансформувалося в об'єктивний процес.

3 позиції сучасної антропології, здатність до абстрагування та узагальнення з'явилась у людини тоді, коли вона постала перед проблемою пояснити собі переміни у власному тілі, які несуть страждання та є ознакою певного захворювання. Тоді людина й починає осмислювати себе, як зовнішній об'єкт з позиції свого “Я”, яку суб'єкта “внутрішнього”. Раніше людина перебувала у стані чуттєво-тілесної неподільності власного Я від зовнішнього світу і була 
безпосередньо залежна від зовнішньої реальності. Тепер людина народжує психічну здатність абстрагувати та узагальнювати, і, таким чином, звільняється від нероздільності себе, як пізнаючого суб'єкту, від себе, як пізнаваного об'єкту. Зародження самосвідомості - й було, власне, актом спрямування людиною пізнавального процесу на себе, пошук у собі недоліків, вад, патологій та їхнього пояснення.

Міфологічна картина світу, попри усі намагання подолати обмеженість первісного окультизму, ще не набувала статусу абсолютної всезагальності, і тільки зі становленням ідеї єдиного бога та закладанням фундаменту монотеїстичних релігій, ідеальні поняття та категорії набувають непорушного обов'язкового для всіх характеру. Становлення віри в єдиного бога-релігії цікаво трансформує й визнання надприродного. Віра у надприродне - це вже не стільки страх перед спонтанними руйнівними явищами та процесами в навколишній природі, але й настільки ж болючий страх перед непрогнозованим перебігом різноманітних патологій. Попри часову обмеженість нашого біологічного віку та географічну прив'язаність до тієї чи іншої ландшафтної території, ми мислимо так, якби запланували жити вічно, та діємо так, немовби маєм наміри засвоїти всі білі плями на карті Всесвіту. Пафос трагічного релігійного оптимізму надає змогу нам вижити за будь-яких обставин, надає сили подолати найскладніші недуги. І, навіть перебуваючи хронічно хворими, з ураженими органами, скаліченими, ми пізнаємо світ, як абсолютно повносправні.

Медицина, сформована у соціальний інститут внутрішньої політики держави, як це зауважив професор І. 3 Держко, зобов'язана не тільки лікувати тіло, органи, клітини, але й нагадувати та допомагати людині йти складним шляхом боговтілення та богоуподібнення. На його думку, це - єдиний шлях нашого спасіння, це шлях збереження нашої гідності, це вірність собі, як духовній істоті, до останнього земного подиху.

Інтегральна медицина людства реалізує себе через родову тотожність нашого Я самому собі, як особистості. I якщо цивілізація Сходу тисячоліттями розвивається шляхом так званого мінімального втручання у Всесвіт (стародавній Китай назвав цей шлях, що пропонує максимум результату при максимумі обмеженого маніпулювання тілом природи та тілом людини, У-срей, то європейська хірургія - це різноманіття гострих втручань та рекомбінацій, пластика, нарощування тканин, протезування, пересадка органів та інші рукотворні дійства. Китайські медики розрізняють більше 400 видів пульсу та здатні діагностувати пульсографією найзамаскованіші патології. Успішні терапевти Заходу в середньому розрізняють до 40 видів пульсу. Завданням медицини планетарного масштабу є системне поєднання здобутків Сходу та Заходу - як вірувань, так і культур, як науки, так і звичаєвого досвіду. Цивілізація майбутнього - це невпинний рух здоров'я, як принципу "мати” заради досягнення щастя, як принципу "бути".

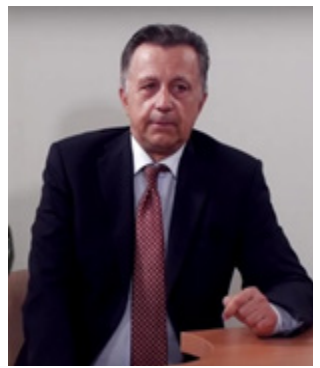

Профессор Ф. Я. Ступак у своїй доповіді на тему “Гуманні засади милосердя і медицини в Київській Русі" проаналізував особливості лікування у Київській Русі, яке, на думку доповідача, не замикалося лише монастирськими стінами. Паралельно з храмовою медициною існувала й медицина світська. Центрами ії були великі міста, передусім Київ. При князівському дворі були лікарі, носії придворної або князівської медицини. Першим лікарем, ім'я якого дійшло до нашого часу, був лікар київського князя Володимира Іоан (Іван) Смеря. За князювання Ярослава Мудрого був лікар, ім'я якого невідоме, але за словами літописця, “бывший зело хитер бе врачеванию яко таков не бе преже всего”. Врешті, до наших днів дійшло ім'я ще одного лікаря - Петра Сиріянина, який “живяше в Киеве, врачуа многы”. Князівські лікарі обслуговували князя, його сім'ю і найближчих князю дружинників.

Серед лічців, тобто, лікарів-професіоналів, були й іноземці (греки, вірмени та ін.). Вод- 
ночас, велике поширення мала народна медицина. Цілителі з народу (знахарі, костоправи, травники, зубоволоки) були носіями цінного медичного досвіду, що передавався з покоління в покоління, і користувалися довір'ям населення. Перших київських лічців слід вважати професіоналами, а не знахарями. Адже важко припустити, щоб князь та його близькі довірили б себе знахарю, а останній узявся б за оперативне лікування князівського сина, як це було, за літописом, у 1076 р., хоча щоправда, й невдале. 3 іншого боку, й серед монастирських лічців були такі, яких можна зарахувати швидше до лічців-професіоналів, ніж до знахарів. ... в “Печерському патерику" розповідається про двох київських "лічців"-професіоналів кінця XIXII століть - Агапіта і Вірменина, які користувалися великою популярністю серед населення Києва і, певною мірою, конкурували один з одним. На підвалинах доброчинності та медичних знань Київської Русі відбувався в подальший розвиток та формування медичної галузі знань.

Завідувач кафедри суспільних дисциплін Запорізького державного медичного університету, професор І. Г. Утюж у доповіді "Філософрія здорового життя: концептуальні смисли А. Лоуена" закцентувала увагу учасників на тому, що "стикаючись із сотнями медичних історій взаємовідношень лікарів та пацієнтів, ставлення лікарів до своєї справи, ми звернули увагу на те, що чимала увага приділяється фізичному аспекту хвороби

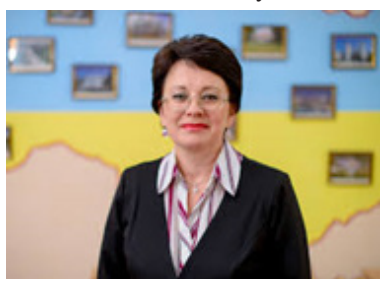
людини, полегшенню тілесних страждань, купіювання симптомів захворювання, і дуже мало саме душевному стану людини, її внутрішнім переживанням, хвилюванням і конфліктам. Але для лікаря будь-якої спеціальності, на нашу думку, вкрай необхідно звертати увагу саме на душевний стан своїх пацієнтів, приділяти увагу спілкуванню з ними”. Саме з огляду на це вона у своїй доповіді й представила деонтологічні основи праці А. Лоуена "Одухотвореність тіла: біоенергетика для благодаті та гармонії”, де автор вдався до аналізу психосоматичних станів, внутрішніх проблем людини, вправ для подолання внутрішніх психологічних проблем, які так часто $€$ прихованими причинами різних хвороб. Формулювання засад біоенергетики на теренах США власне й належало цьому американському психіатру і психотерапевту, який у своїй концепції спирався на дослідження В. Райхом енергетичної основи психофізичних процесів.

Біоенергетика розглядає функціонування психіки людини в категоріях тіла та енергії, вважаючи джерелом неврозів, депресій, пригнічення почуттів, що проявляється у вигляді хронічних м'язових напружень, що блокують вільний потік енергії в організмі. В ранньому дитинстві проявляються, а потім закріплюються специфічні навички уникнення болю, розпачу, страху та засоби отримання безпеки та любові оточуючих. Вони призводять до розвитку структури характеру людини, що складається з часто викривленого образу світу та власної особистості, ригідних схем поведінки та відчуттів, а також обмежує життєвість організму патернів "самовладання", що називається також “панцирем характеру”. Таким чином фрізичний вигляд людини символічно відображує її психіку.

Як бачимо, А. Лоуен у своїй роботі, акцентує увагу на тих речах, від яких наша медицина дедалі більше відходить, акцентуючи увагу лише на наборі конкретних симптомів для кожної конкретної хвороби, певних лабораторних та інструментальних методів діагностики, звичайних стандартних схем лікування. Але проблема діагностики та лікування хвороб лежить значно глибше та криється в глибинах людської психіки.

А. Лоуен наголошує на тому, що хвороби організму можна зрозуміти тільки шляхом цілісного підходу до людини.

Автор визначає чіткі смислові константи правила біоенергетики, воно полягає в тому, що людина втрачає контакт із кожною частиною тіла, де присутнє хронічне м'язове напруження. Чим більш жорстоким стає тіло, тим менше стає в ньому відчуттів, і тим більше воно стає подібним до машини. Мозок такої людини стає більш активним, і людина починає засновувати 
"самовідчуття" виключно на своїх розумових процесах. Тіло стає апаратом для перенесення голови та створення нею думок. У такій людині мало життя та духовності.

Багато людей скептично ставляться до понять і значної ролі психосоматики у виникненні різних захворювань. Але ж чому тоді позитивний емоційний стан так часто допомагає одужувати від хвороби набагато швидше, аніж коли пацієнт знаходиться в пригніченому стані, загнаний власними страхами та переживаннями.

Звертаючись до поняття сенсу людського життя не можна не згадати значення, яке відіграє релігія в житті багатьох людей. На думку А. Лоуена, релігія для людини психотерапевтичний інструментарій самолікування, який дозволяє наблизитись до гармонії з самим собою і людьми, до природи, до духовного росту і самозбереження. Нажаль, відмічає автор, така смислова парадигма не властива людині західного світу, на відміну від східної культури і цивілізації. "На Сході люди не тільки зберігають анімістичні уявлення, але й більше вірять в оздоровлюючу міцність тіла. Ця віра не відкидає, звісно, допомоги, яку, наприклад, може надати антибіотик у боротьбі з гострою інфекцією. Тим не менш, твердження, що віра творить дива, правдиво. В дуже багатьох документально підтверджених випадках віра змінила прогноз смерті, та факт одужання виглядав як чудо. Ці чудеса однак не є результатом діяльності таємних зовнішніх сил, що входять у тіло для того, щоб вилікувати хворобу. Таке розуміння надає в основному сучасна медицина, звертаючись за допомогою ліків та інструментів. Віра діє зсередини, хоча може бути замінена досвідом любові" (Lowen, 1990).

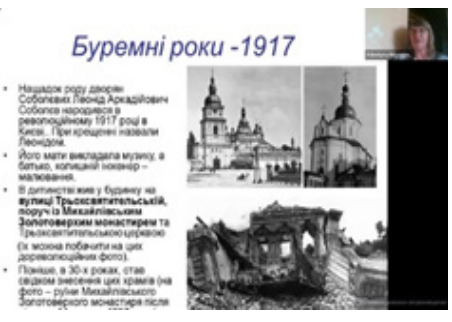

У доповіді "Киянин О. Пимен - талановитий церковний композитор, іконописець, будівельник православних храмів" професоа кафедри пропедевтики внутрішньої медицини № 2 НМУ імені О. О. Богомольця В. О. Мойсеєнко була представлена непересічна постать отця Пимена - інтелігентної людини і громадянина, який був особистістю політично освіченою, співпереживав і оцінював політичні події в країні і в світі. Доповідач навела цікавий фракт: зберігся лист-телеграма (1975) отця Пимена в Білий дім, в якому він звертався до президента США з проханням припинити дискримінацію над чорношкірим пастирем, ув'язненим за діяльність по захисту чорношкірих християн. "Дивом було саме життя отця Серафима, - наголошувалося в доповіді, - кілька десятиліть він, інвалід першої групи, жив з діагнозом "рак". I люди, що жили поруч з ним, теж на роки забували про свої, часто невиліковні, хвороби - і ті відступали. Невеликий скит на околиці Києва зараз знають у всьому світі”.

Доповідь завідувача кафедри філософії та біоетики Одеського національного медичного університету професора В. Б. Ханжи “Божий промисел і людська свобода: міжепохальний діалог Блаженного Августина і Святителя Луки Кримського" звернула у вагу на те, що людина часто сама обирає неперспективний шлях, а відбувається це через слідування незмінним бажанням: “Преисполненное злом сердце человека побуждает его изливать негатив в отношении иных людей. Поэтому путь преодоления зла должен иметь начало в изгнании такового из человеческого сердца, в очищении сознания от дурных помыслов... Естество этого пути - в единении человека с Богом, символом чего и явля-

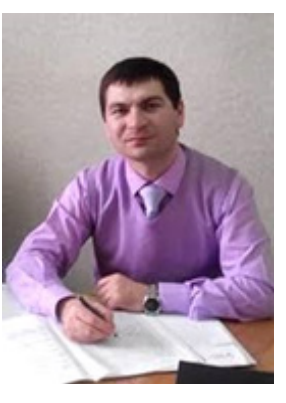
ется жизнь Христа. По замыслу Всевышнего жертва Иисуса выступила, таким образом, как этический эталон, наглядно демонстрирующий пример величайшей любви к роду человеческому”. Отже, підсумував доповідач, "на думку святителя Луки Кримського, вирішення питання про співвідношення Божого промислу і людської свободи здійснюється наступним чином. 3 одного боку, проголошуючи тотальність Божого провидіння, він, з іншого боку, підкреслює 
самостійність людської свободи волі, яка, однак, знаходить повноцінну силу і підтримку Божої Благодаті тільки в разі спрямованості на благо".

Про “Практичне випробування релігійної біоетики в умовах коронавірусу” поінформував учасників конференції професор кафедри богослов'я та релігієзнавства НПУ ім. Драгоманова Ю. П. Чорноморець. Доповідач зауважив, що “біоетика, як вона пропонується християнським соціальним вченням для світського середовища, виходить із тези про унікальну гідність особистості. А саме, кожна особистість $є$ абсолютною цінністю з моменту власного зачаття і до своєї природної смерті. Релігійна біоетика постійно підкреслює, що обов'язком лікарів та медичного персоналу є підтримка цієї особистості, навіть у ситуаціях, коли соціальна цінність цієї підтримки є сумнівною, а затрачувані ресурси непропорційно великими". В доповіді також підкреслюється, що "відповідальне ставлення до небезпеки і повне закриття культових споруд з міркувань безпеки вірних, життя яких оголошувалося вищою цінністю, продемонстрували не лише католики, ПЦУ, українські протестанти, але також іудеї та мусульмани України. Все це говорить про високу соціальну відповідальність та дотримання принципів релігійного гуманістичного персоналізму практично всіма церквами і релігійними організаціями України".

Продовжив тему “COVID-19" доцент М. В. Жук, завідувач кафредри соціально-гуманітарної освіти комунального закладу Сумський обласний інститут післядипломної педагогічної освіти доповіддю "COVID-19 як фактор розвитку освіти та формування людського капіталу”. Доповідач підняв такі проблеми: особливості реалізації тренду "4 C" (collaboration, communication, creativity, critical thinking) в навчанні поколінь "Z" та "A", особливо за умов карантинного дистанційного навчання; зупинився на викликах

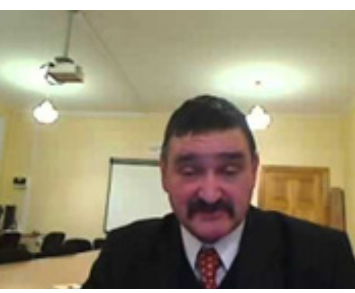
розвитку освіти у вимірі 2020+ (вимір 4.0 як фактор зміни формату Life Learn Learning: IY промислова революція (ВЕФ, 2016), Глобалізація 4.0 (ВЕФ, 2019), потреба нових технологій для навчання поколінь цифрових поколінь "Z" та "A"); висловив своє бачення нових викликів які впливають на освітній процес і освітню комунікацію (COVID-19), зокрема, перспектив дистанційного навчання за умов карантинів, зростання сегменту змішаного навчання (Blended learning), збільшення сегменту digital society (economy, education, communication); узагальнив ресурси (практики) з проблеми впливу COVID-19 на освітній процес і освітню комунікацію, показав можливості адаптивного менеджменту та індикативних технологій на прикладі дорожніх карт; проаналізував проблему COVID-19 з позицій потреби нового освітнього ландшафту, обгрунтував наступні тези: дистанційне навчання не є копією традиційного навчання. Це інша модель комунікації; навчання - процес багаторівневої комунікації; необхідність активізації використання аналогового досвіду та індикативних технологій для прискорення процесу адаптації до нових практик.

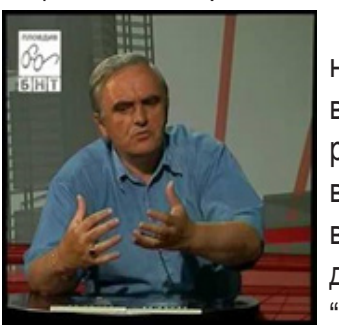

Відповідь на питання "Чому ми повинні захистити, передусім, наші серця, або коли наш дух є здоровим?" стала лейтмотивом доповіді директора Центру розвитку особистості "HUMANUS" А. Гранчарова, який екстраполював вічні біблійні істини на сучасність і дійшов висновку про те, що справжнє серце варто розуміти саме як "духовне серце". Свідченням вічного характеру біблійних істин, на думку доповідача, є напис на вході до гірської хатини Мартіна Гайдеґера: "... Найбільше бережи своє серце: адже воно є джерелом життя!". Як зауважив доповідач: “Без серця не можна жити, життя безсердечної людини - жалюгідне. Серце, крім усього іншого, є джерелом нашої людяності, серце нас олюднює - бо розум хоче зробити з нас машини, роботи, комп'ютери. Без серця немає душі, немає сенсу, без серця немає нічого. Безсердечна людина - це щось на зразок зомбі, наче жива, але насправді мерт- 
ва. Навколо нас повно таких людей, я не знаю, чи Ви це помітили?! Безсердечна, нечутлива людина - духовний інвалід, який не розуміє найголовнішого. У нього повністю деформована психіка. У нього дуже нещасна душа. Він багато страждає і на цій підставі, оскільки не може засвоїти свої постійні страждання, він настільки злиться, що стає лиходієм". А. Гранчаров закликав не забувати, що "Бог дивиться не на обличчя людини, а в серце. I якщо ми можемо обдурити оточуючих людей через оманливе самосприйняття, то ми не можемо обдурити Бога.Сучасна людина багато зусиль витрачає на тіло, матеріальне, тимчасове, а не духовне. Благословенні ті, що чисті серцем, бо вони побачать Бога".

Дилема "Маркетизації медицини та супротиву сумління" розглядалася у доповіді доцента С. Капікової з Інституту соціальної медицини та медичної етики медичного факультету Університету імені Коменського в Братиславі. Доповідач зазначила, що "ми переживаємо часи нормативного плюралізму та релятивізації цінностей. Разом з розвитком природничих та інформаційних наук, складних біотехнологій, сучасна медицина здатна не тільки контролювати патологічні процеси в організмі людини, але і веде до вдосконалення людського організму, проектування та впливу на біологічні риси ненароджених людей. Недостатньо регламентоване використання біотехнологій призводить до дуже сильних ціннісних конфрліктів, етичних дилем і є складним правовим рішенням. Ми переживаємо сильну тенденцію маркетизації медицини ... У лікуванні людей принципи економічної доцільності стають визначальними, не враховуючи наслідки для здоров'я людей - наприклад, лікарі застосовують медичні або псевдомедичні методи лікування, такі як гомеопатія. Центри охорони здоров'я надають низку послуг із використанням біотехнологій "на замовлення", які пацієнт замовив та оплатив. Тіло людини та його органи зводиться до компонентів та матеріалів, які можуть бути предметом торгівлі, таких як гамети, сурогатне материнство тощо. Отже, совість (сумління) людини є дуже важливим механізмом регулювання поведінки людини, особливо в медицині". У доповіді докладно проаналізовано Деонтологічний кодекс Словацької медичної асоціації, який містить правила етичної поведінки для представників медичної професії. Виходячи з його засадничих положень, доповідач виголосила наступні висновки: “Захист життя та здоров'я людини, людська гідність - це цінності, що випливають з християнства та є частиною європейських культурних традицій. Захист та втілення цих цінностей останнім часом є непростим для медичних працівників. Великим викликом є правове регулювання медицини. Якість закону визначає захист супротиву сумління. Медичні працівники заслуговують на справедливі умови праці для виконання роботи, які гарантують їм недискримінацію у трудових відносинах".

Доповідь "Відповідальне надання медичної допомоги в постосекулярній ситуації глобальної кризи людства” доктора філософії кафедри етики та моральної філософрії філософського факультету Трнавського університету К. М. Вадікової була спрямована на висвітлення сучасних атак, спрямованих на людство, які випливають із ситуації швидкоплинності попередніх стабільних структур мислення щодо таких етичних категорій, як добро, зло, правда, любов, відповідальність, справедливість, людина тощо. Доповідач переконана у необхідності автономної реакції дива перетворення у глибокій близькості до внутрішнього світу ситуативної людини. Такий акт воскресіння неможливий у глобальному масштабі, бо - це шлях від совісті до совісті як безперервної відповіді на поклик

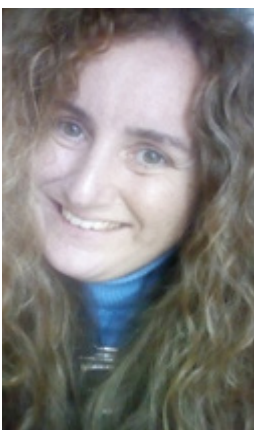
справжнього "Я", а не швидкоплинного добра". "Водночас, глобальну загрозу для людства можна подолати лише разом (у діалогічних міжособистісних відносинах, де залучена Божа сила); особистим відповідальним рішенням про глобальну співпрацю, прийнятим кожним із членів людства окремо. Надію, любов, віру, а також біль, смуток тощо слід розділяти і лікувати в процесі діалогічного обміну. Діалогічне спілкування, що ґрунтується на повазі до людської 
гідності, може розглядатися як основний метод відповідального надання медичної допомоги в постсекулярну добу. Таке відповідальне надання медичної допомоги демонструє свої переваги, особливо у спробі вирішити глобальні біоетичні проблеми - зокрема, і такі, з якими ми сьогодні зіткнулись через коронавірус "Covid 19". Від усіх особистих відповідальних рішень залежить спільна боротьба за добро (у діалогічних відносинах), щоб мати можливість подолати не тільки фізичну інфекцію, але; також зараження душі та духу, викликане культурою споживацтва або глибоким ізоляціонізмом або егоїстичним вихованням широкої толерантності. Вже немає місця для виправдань, ухилень чи будь-якої безвідповідальної поведінки. Адже, як слушно наголосила доповідач, "постмодерна доба вимагає особистого відповідального рішення залишатися моральною людиною в постсекулярному суспільстві. Будь-яка система охорони здоров'я та система догляду зруйнується без співпраці всіх її частин у діалозі та в узгодженні єдиної мети. Основою розвитку будь-якої системи охорони здоров'я має бути особиста, а не тимчасова відповідальність. Це має бути особиста відповідь від свого імені у формі заклику до всього доброго в людській гідності - що повинно бути постійно контрольованим, принаймні, власною совістю і стверджуватися в діалогічних відносинах".

Загалом у форматі відео-конфреренцій були проведені пленарне та секційні засідання, на яких виступили, взяли участь в обговореннях понад сто учасників. Принагідно відзначити необхідно і традиційне проведення студентського секційного засідання, до участі в якому цьогоріч долучилися й клінічні ординатори факультету підготовки іноземних громадян (Азербайджан, Куба, Туркменістан) з кафедр анестезіології та інтенсивної терапії, акушерства та гінекології №3, ортопедичної стоматології НМУ ім. О. О. Богомольця.

Учасники II Міжнародної науково-практичної конференції "Філософія релігії та медицини в постсекулярну добу" в плідних дискусіях, обговореннях та дебатах висвітлювали проблеми творчої взаємодії медицини та релігії, спираючись на новітні досягнення медичної науки. Представниками кафедри філософії, біоетики та історії медицини НМУ імені О. О. Богомольця розширено наукові контакти для подальшої співпраці між українськими та закордонними фахівцями, зокрема з Трнавським університетом (Словаччина), від імені якого К. М. Вадікова запросила взяти участь в міжнародній міждисциплінарній конференції "New Models of Evasions. Out of Personal Responsibility: Slovakia and Europe" та Одеським національним медичним університетом, від імені якого професор В. Б. Ханжи запросив взяти участь в III Міжнародній науковій конференції “Людина як цілісність: філософський, психологічний, медичний та юридичний полілог - від теорії до практики". Усі учасники конференції здобули неоціненний практичний науковий досвід живого спілкування, участі в дискусіях, дебатах, висвітленні та вирішенні злободенних проблем інтеграції релігії та медицини в сучасну інформаційну добу. Усім спікерам та учасникам конференції було надіслано поштою програми та збірники матеріалів конференції, сертифікати учасника конференції, почесні грамоти та подарунки.

У заключній доповіді. проф. І. В. Васильєва подякувала усім учасникам за плідну працю та запросила взяти участь у наступній III Міжнародій науково-практичній конференції "Філософія релігії та медицини в постсекулярну добу", присвяченій пам'яті свт. Луки (В. Ф. Войно-Ясенецького), яка відбудеться уже традиційно 11 - 12 червня 2021 р.

\section{Література}

Філософрія релігії та медицини в постсекулярну добу: матеріали I/ Міжнар. наук.-практ. конф., присвяченої пам'яті свт. Луки (В. Ф. Войно-Ясенецького) (2020), НМУ ім. О. О. Богомольця, ВР ІФ ім. Г. С. Сковороди НАНУ, Київ, 251 с.

Lowen, A. (1990), The Spirituality of the Body: Bioenergetics for Grace and Harmony, Macmillan, New York, 209 p. 


\section{References}

Philosophy of Religion and Medicine in the Post-Secular Age: materials of II the international Scientific and Practical Conference. In memory of St. Luke (V. F. Voino-Yasenetskyi) [Filosofiya religiyi ta medycyny v postsekulyarnu dobu: materialy II Mizhnar. nauk.-prakt. konf., prysvyachenoyi pam'yati svt. Luky (V. F. Vojno-Yasenecz 'kogo)] (2020), O. Bogomolets National Medical University, Department of Religious Studies of the Skovoroda Institute of Philosophy of the National Academy of Sciences of Ukraine, Kyiv, 251 p.

Lowen, A. (1990), The Spirituality of the Body: Bioenergetics for Grace and Harmony, Macmillan, New York, 209 p.

\section{() Ірина Василівна Васильєва, Сергій Леонідович Шевченко, Оксана Вікторівна Романюк}

